\title{
Notary Role In Agricultural Land Rent Agreement In The Village Of Tungu Godong District Of Grobogan
}

\begin{abstract}
Ani Hilyani ${ }^{1}$, Tofan Alamsyah ${ }^{2}$ and Aryani Witasari ${ }^{3}$
Abstract. The purpose of this research are: 1) To determine the role of the Notary in the implementation of the agreement rented farmland in the village of Tungu Godong District of Grobogan. 2) To know the rental renting Agricultural Land In the village Tungu Godong District of Grobogan. 3) To know the constraints in the implementation of the lease meyewa farmland and the solution of these constraints. The method in this research sociological juridical This study is based on positive law in Indonesia and is based on existing practices in the community. So paties directly relate to both parties, including the people who do agricultural land lease agreement.

Based on the analysis of this study concluded that the role of the Notary in the lease agreement of agricultural land is the agreement made before a Notary with the deed of lease agreement, the lease which is carried out in the village Tungu done by those who do the lease agreement in line of sight crushing price to be agreed, if it is agreed the lease agreement was publishes an agreement in the agreement, such as a lease, the lease payments. The obstacles in the process of leasing such as crop failure, it is also common pests and the solution of these problems are minimized losses by means of land rent farmers cultivating land in addition to the main cropping namely rice, do matcher other crops such as corn.

Keywords: Role of the Notary; Rent Agreement; Land of Agriculture.
\end{abstract}

\section{Introduction}

Soil is the uppermost surface of the earth, the soil as a natural resource is a gift from Allah SWT that is given to man to be taken advantage. For the people of Indonesia, in this eraglobalisasi development everywhere that all development must be in need of land, land is the most fundamental problem of the number of civil and criminal cases filed to court ranged dispute regarding land. Principle followed by Indonesia against the soil has been reflected in the BAL.

State of Indonesia as a developing country that still relies on agriculture and land that became the foundation of agriculture is the principal means in agriculture, on this soil hold people can live their lives. In addition to limited land for him and can not afford renewed. Land bias established buildings, home to Man company work, land for Man stand to walk besides the need for land Man is also very important for the life of plants and animals for survival. For Indonesian people, land is the most fundamental problem of the number of civil and criminal cases filed to court ranged dispute regarding land. Principle followed by Indonesia against the soil has been reflected in the BAL. ${ }^{4}$ The area is owned by the nation independent and united, the whole of Indonesia is the

${ }^{1}$ Student of Master of Notary Program, Faculty of Law Sultan Agung Islamic University, Semarang, Email: anijeketro@gmail.com

${ }^{2}$ Student of Master of LAw, Faculty of Law Sultan Agung Islamic University, Semarang, Email taufanalam7@gmail.com

${ }^{3}$ Lecturer, Faculty of Law, Sultan Agung Islamic University, Semarang

${ }^{4}$ Achmad Chulaemi, 1992, Pengadaan Tanah Untuk Kperluan Tertentu Dalam Rangaka

Pembangunan, Majalah- Majalah Hukum, No. 1, FH. Diponegoro University, Semarang, p. 9 
unity of the homeland of all the people of Indonesia to the relationship that is enduring ${ }^{5}$.

Land as a place where the living and the land citizen placed provide livelihood for him. ${ }^{6}$ Land is something has a value that is very important in people's lives, it is because the land has an economic value, magical-religious cosmic point of view of the Indonesian nation, he also frequently gives vibration in peace and often give rise to shake-up in the community, and he is also a frequent raises flashlight in the implementation of national development. ${ }^{7}$ State of Indonesia as a developing country that still relies on agriculture and land that became the foundation of agriculture is the principal means in agriculture, it has been stipulated in the Constitution of 1945, Article 33 paragraph (3), namely "Earth, water and natural resources contained therein controlled by the State and used for the greatest prosperity of the people".

The area is owned by the sovereign nation and united, the whole of Indonesia is the unity of the homeland of all the people of Indonesia to the relationship that is enduring $^{8}$, Testament in the book of Civil Law (KUHPeradat) governed by Article 1313, namely: a treaty is an act by which one or more persons bind himself to one or more other people. Average lease first definition regulated in book III of engagement in chapter VII of the lease part to a general provision be interpreted as an agreement by which the parties bound themselves to give to the other party the enjoyment of a good. During a certain time and with the payment of a price by the latter party was affordable payment ${ }^{9}$.

Lease is an agreement or arrangement in which the tenant must pay or reward or benefit of objects or items in the rental, and the law is permissible or allowed. Lease in Arabic is called Ijara. Etymologically, the word Ijarah ie wages or rent. According to the terminology of religion is to give an object to another person to take the benefits with the provisions of the person who receives it rewards in return for the use of the benefits of goods in use ${ }^{10}$,

One lease agreement is a leasing farmland, lease farmland in Islam was the exchange of wealth is agricultural land in exchange for a sum of money between the one with the other and each party getting its due with the provisions of a period of time, the value of lease or rental period is not clear, making the contract forbidden in Islam.

Problems of agricultural land is so complex, the modern era like now increasing need for land is so great but it is not matched by the provision of adequate agricultural land, which spurred the lease of agricultural land, which became one of the alternatives by the public. It happens because on one hand there are people who have a vast agricultural land but can not process it, and the land unproductive or other problems this community does not have the capital and on the other hand there are people who have the capital and a desire to lease the agriculuture land. They have a forward thinking without having to think of farming land, and therefore the lease agreement and the farmland appear to be important, it is important for tenants,

\footnotetext{
${ }^{5}$ Suryani Hartono, 1978, Beberapa Pemikiran Kearah Pembaharuan Hukum Tanah Bandung, p.

${ }^{6}$ Soerjono Soekanto and Solemab B. Taneko, 2001, the Indonesian Indigenous, King Grafindo Persada, Jakarta, hlm.172

${ }^{7}$ Pahala Marihot Siahaan, 2003, Hukum Adat Indonesia, Raja Grafindo Persada, Jakarta, p. 32

${ }^{8}$ Suryani Hartono, 1978, Beberapa Pemikiran Kearah Pembaharuan Hukum Tanah, Bandung, Alumni, hlm.5

${ }^{9}$ Prof. R. Subekti and R.Tjitrosudibio 2008, Kitab Undang-Undang HUKUM PERDATA, Jakarta, Pradnya Paramita, hlm.381

${ }^{10} \mathrm{http}: / /$ coretan-berkelas.blogspot.com/2013/11/pengertian-hukum-rukun-dan-syarat-sewa.html On October 27, 2019 at 15:30
} 
Volume 7 Issue 1, March 2020

Nationally Accredited Journal,

Decree No. B/4130/E5/E5.2.1/2019

\section{Research methods}

The method in this research sociological juridical. This study is based on positive law in Indonesia and is based on existing practices in the community. So Belak directly relate to both parties, including the people who do agricultural land lease agreement.

Specifications in the research is descriptive analytical, research on this lease agreement using descriptive analysis to obtain results as accurate facts.

Methods of data collection in this research that is by the method of interviews conducted against those who do agreement lease of agricultural land which also involve the Community to be rented farmland. The research method of guided interviews with a free way means: prior to the interview subjects researchers prepare Your question however does not reduce freedom in the interview process. Sample here purposive sampling are related parties in accordance with the correlation, competence and capability the head of the village, Notary Public.

This research was conducted using qualitative descriptive with direct search, collect the data directly on the object of research by describing in accordance with the facts that are accurate, source of research data using secondary data directly to obtain the data and also uses primary data collected from books, journals and more.

\section{Results and Discussion}

\subsection{The role of the Notary in Agricultural Land Lease Agreement}

In the lease agreement agricultural land Notary very important role to provide legal certainty, justice and member benefits to the parties to implement the agreement Rent renting of agricultural land with a deed lease, because the deed he made are authentic and can be used as a means of proof strong and when there are problems associated with the rental agreement to lease land in accordance with article 1320 of the Civil Code.

The conditions required for legality an agreement on Article 1320 of the Civil Code is that there are four requirements: They agreed that bind himself; Ability to create an engagement; A certain thing; A cause that kosher.

In this case the lease agreement meets the objective and subjective elements, if one of the conditions is not fulfilled, the agreement was illegal and biased canceled by operation of law. In this case the parties have come to face the Notary to lease farmland, rental renting farmland in Village Tungu done for the people's welfare, in agreement Rent hire may not have the feel disadvantaged in the process of execution of the lease agreement is, so here Notary making land lease agreement with the will and the agreement of the parties, the parties provide the requirements that must be met to make an agreement, then the Notary make land lease agreement with a corresponding price agreement with place and the results obtained, because each place have a price different, and the path to be taken also affect the price of the lease, in addition to places and roads, rental price also depends on the surrounding water, because the water is affecting the cultivation of crops and the results. Notary Deed play an important role in providing assurance of the authenticity of law because 
properties and can be used as evidence increasingly tie along with increasing business relations in various fields of business from local to international. ${ }^{11}$

\subsection{Agricultural Land Rental Process In the Village of Tungu Godong District of Grobogan}

The village has assets that can be used by society village Tungu for the prosperity of the people, assets dition, too, not least, assets such as agricultural land is also very able to help people who have minimal capital, in addition to the farm village Tungu also owns the asset market in the rental with a special cost to society Tungu village is by the rental price Rp.1.500.000. rupiah per year with cheap rents Tungu Village community can use the remaining money to buy capital goods going to sold again. Village party providing the means or the village authorities to facilitate the auction. Village Tungu facilitate a lease by way of the first auction committee must be made in advance, after the formation of the committee lease of agricultural land through auctions lands want to rent a way tendered must be recorded prior the auction committee, between the wide position and the owner's name first benchmark price for the auction. Lease by auction include an easy way to get prosperity of communities and provide justice by giving the widest opportunity for the public to rent farmland by being able to choose the land in accordance with the money they have, so prospective tenants they come village hall to bring some amount money and attend the auction facilitated Tungu village funds.

Implementation of the lease agreement of agricultural land in the village of Tungu subdistrict Godong Grobogan already set in the regulation of the village head Tungu District of Godong Grobogan No. 02 of 2017 concerning the lease / land auctions village treasury Tungu Godong District of Grobogan of 2017 with a committee was formed lease / auction regulated in chapter III of Article 7 of the tender committee consisting of three (3) paragraph. In Article 7 paragraph (1) contains the making of the supervisory committee and the committee of the auction of land the village treasury to ensure the smooth implementation of the lease / tender by the head of the chief.

In Article 7 (2) describes the task of supervising committee village land auction cash as referred to in paragraph (1) shall include:

- Attend and overseeing the village treasury land auction;

- Provide advice and input on the implementation of village land auction cash;

- Facilitation problems that arise in the implementation of village land auction cash; and

- Carry out evaluation of the village treasury land auction.

In Article 7 paragraph (3) describes the implementation committee assignments village land auction cash as referred to in Article 7 paragraph (1) shall include:

- Establish ground the village treasury auction schedule after coordinated beforehand with the supervisory committee;

- The official report of auction and make the concept of the rental agreement;

- Receiving money from the auction and then depositing the village to bill instituted local banks;

- Report the results of the auction of land the village treasury to the village chief.

Implementation of the lease of agricultural land in the village of Tungu already designed one month before the lease by auction was conducted by making committee

\footnotetext{
${ }^{11}$ Sjaifurahman and Habi Adjie, 2011, Aspek Pertanggungjawaban Notaris dalam Pembuatan Akta, Bandung, p. 8
} 
and disseminate announcements ${ }^{12}$ And execution of a lease of agricultural land by auction is conducted in accordance with the Regulation of the Village Head Tungu Godong District of Grobogan No. 02 of 2017 on the rental / auction Cash Land Village Tungu Godong District of Grobogan of 2017 also describes the implementation of the lease / auction is set on the third part of exercising their lease / auction Article 4, namely: in the implementation of the lease cash village land Tungu committee will execute lease in accordance with the list of participants, the organizers rent or auction stipulated in the Village Head Tungu District of Godong Grobogan No. 02 of 2017 on the rental / auction cash land Village Tungu Godong District of Grobogan of 2017.

Registration is stipulated in the Village Head Tungu GodongDistrict of Grobogan No. 02 of 2017 on rent / auction Cash Land Village Tungu Godong District of Grobogan of 2017 Part Two of the registration of participants at Article 3 that contains two paragraphs on the first verse of participants present application for registration by filling forms / form provided by the organizers to include location / parcel / land block village treasury interest to hire. Moderate second paragraph committee made a list of participants for the rental / auction based on the interests of participants in the respective parcels each. Then people who want to participate in the auction must follow the appropriate procedure in Article 3.

In the case of applicants a location / parcel / land leased blocks 1 (one) then the buyer immediately set as a tenant at the rates approved BPD (Village Consultative Body). ${ }^{13}$

How should an auction conducted by auction in general, iein the auction process in the set basic price and between two (2) or more persons will be mutually eagerly to compete for agricultural land wanted to be hired by the village residents and provided the value of the highest bid will get the right lease of land cash Village on parcels / block of land desired. For the tenant shall pay the rent at the time of the determination as a tenant with a provision to pay CASH / FULL PAYMENT.

In an auction attended by people which want to do a lease / auction of land in the village of Tungu they are already eyeing a site / parcel / specific block and have set the money on the basic price or more, because the people who follow the lease / auction process that desire a parcel / location / block certain land must pay with cash in full or when he is determined as the winner, the winner here is the highest bidder of the tender process to hire a site / parcel / block of land in the village Tungu. A different way of renting farmland first is the other way directly desire the side desire written in the articles are written and explained by the parties, such as the prices agreed between the tenant and the rent being Notary costs borne by them, in accordance with the agreement. In addition to the price of the lease agreement also agreed on how many times the harvest in the rental, because the rental agreement renting farmland harvest counted not in accordance with international treaties and agreements. Village Community of Tungu majority of the agricultural society or community farmer, every land that could be used to let through an auction or directly hired to supplement the income of the village and revenue tenant or community that

\footnotetext{
${ }^{12}$ According to interviews with Mr. Ahmad Rifa'i as Tungu village secretary, on Wednesday, January 31, 2018.

${ }_{13}$ Regulation village chief Tungu Godong District of Grobogan No. 02 of 2017 on the lease /

Cash Land auction Tungu Village Subdistrict Grobogan Godong Year 2017
} 
benefits both parties, the one as its own agricultural land to be leased or the second party is the people who rent the farm land ${ }^{14}$

\subsection{Constraints in Implementing the Agricultural Land Rental and Solutions From Such Obstacles}

The process of doing a lease of agricultural land in the village of Tungu Godong District of Grobogan very profitable to the village as a tenant and also beneficial to villagers Tungu as renting farmland, or to the public with the public directly. In the process of renting farmland in the village of Tungu not a few difficulties in implementing the lease of agricultural land, the time of lease agreement of agreeculture land conducted by way of auction is in the process conduct an auction, if a parcel / block / locations who want to farm village only 1 (one) no one prospective tenant with prospective tenants who are mutually heats in determining the price, unlike the case if wanting to lease the land more than one candidate, prospective tenants each other prospective tenants mutuals add to the rental price of agricultural land to obtain a location of agricultural land / parcel / block. The solution to this problem is to pause for a while the process of lease / tender with a little give insight to convince the parties to mutually add the price and committee rental / auction read back the farm land grabs by embroider agricultural land prices, which was read by committee namely between another wide, the results of last year, agricultural land and other locations. After seeing the prospective tenant a little quieter then the lease by auction can proceed. The solution to this problem is to pause for a while the process of lease / tender with a little give insight to convince the parties to mutually add the price and committee rental / auction read back the farm land grabs by embroider agricultural land prices, which was read by committee namely between another wide, the results of last year, agricultural land and other locations. After seeing the prospective tenant a little quieter then the lease by auction can proceed. The solution to this problem is to pause for a while the process of lease / tender with a little give insight to convince the parties to mutually add the price and committee rental / auction read back the farm land grabs by embroider agricultural land prices, which was read by committee namely between another wide, the results of last year, agricultural land and other locations. After seeing the prospective tenant a little quieter then the lease by auction can proceed. ${ }^{15}$ Constraints during the process of lease / tender was that when each other to shout but that sounds only one participant at the same price and whose voice is not heard protests by the committee then the committee will make the process of lease / auction is repeated from the beginning, but only for two participants who shout higher and the same price for a base price determined by Village ${ }^{16}$.

Another problem occurring in the lease agreement of agricultural land in the village of Tungu namely the issue of payment, ie payment after selecting tenants of the most high and must immediately pay in full and in cash money as a payment instrument would not be small and the money has a significant possibility that money counterfeit and other possibilities less, if this happens for the lessor is the village will feel the loss as a means of payment is counterfeit or less, then to cope with the possibility that such

\footnotetext{
${ }^{14}$ Results of an interview with Mr. Miftahul Mujib, SE as the Village Head Tungu, on 5 November 2019.

${ }^{15}$ Results of an interview with Mr. Miftahul Mujib, SE as the Village Head Tungu on December $1,2019$.

${ }^{16}$ According to interviews with Mr. Karim as the Committee for rent / auction Tungu village, on 29 November 2019.
} 
Volume 7 Issue 1, March 2020

Nationally Accredited Journal,

Decree No. B/4130/E5/E5.2.1/2019

problems occur committee made a separate team to calculate and checking one by one currency as a means of payment, by counting and checking one by one the money, then the time is used more and more in the process of renting farmland makes the other participants who wish to lease a location / parcel / block be waiting, and the committee must give meaning to the people who want to do the next bidding process ${ }^{17}$.

Constraints not only occur during the process of lease / auction occurs, but also time constraints occur leased farmland in the work on the community, the obstacles in the form of pests that attack farm Tungu village, besides there are also other obstacles pest that is mice. To keep the village agricultural land in order to avoid pests Tungu it must be frequently carried out by spraying certain drugs for in agricultural land should be in spray one week of one or two weeks according lord village of leased farmland. In addition to spraying a particular drug, to guard against the threat that is by crops, crops are rice planting or planting other than stream such as soybeans, peanuts, corn, scallions and others. ${ }^{18}$

\section{Closing}

\subsection{Conclusion}

Based on the description above, the conclusions of this research are:

- Notary very important role to provide legal certainty, justice and member benefits to the parties to implement the agreement Rent renting of agricultural land with a deed lease, because the deed he made are authentic and can be used as a means of proving strong and if there problems associated with the rental agreement to lease land in accordance with article 1320 of the Civil Code. Notary responsible for storing all document related to deed land lease agreement the farm.

- Process Lease Land For Agriculture In the village Tungu have two ways to implement the lease of agricultural land, for which gems directly parties who wish to lease and the second by way of through an auction process conducted with the village, the exclusion is no asset village in rented to the public, and the lease was beneficial to both parties to the lease, and which certainly help people and communities prosper.

- Obstacles that occur in the process of lease agreement of agricultural land in the village of Tungu Godong District of Grobogan not significant obstacles that occur include the time of payment, the time of the lease, the constraints also occur when agricultural land are cultivated and already in anticipation by the committee rental / auction by looking at the previous year agreement.

\subsection{Suggestion}

Based yan research has been done, the study members suggestions:

- Notary emotion has prudence is high, because one of the deed will cancel the lease of agricultural land.

\footnotetext{
${ }^{17}$ Results of an interview with Mr. Purwadi, as Chairman of the committee rental / auction Tungu village, on 29 November 2019.

${ }^{18}$ Results of an interview with Mr. prostration, S, Ag, one of the village residents Tungu Date 6 November 2019
} 
- The process lease agreement / auction of agricultural land in the village Tungu Godong District of Grobogan must be monitored very carefully and put committee society without harming each other.

- For committee rental / auction shall be selected from among those who did not side with the prospective tenant for the smooth process of agricultural land lease agreement.

\section{References}

[1] Achmad Chulaemi, Pengadaan Tanah Untuk Kperluan Tertentu Dalam Rangaka Pembangunan, Majalah- Majalah Hukum, No. 1, FH. Diponegoro University, Semarang, 1992

[2] Suryani Hartono, Beberapa Pemikiran Kearah Pembaharuan Hukum Tanah, Bandung, 1978

[3] Soerjono Soekanto and Solemab B. Taneko, Hukum Adat Indonesia, Raja Grafindo Persada, Jakarta, in 2001

[4] Pahala Marihot Siahaan, Bea Perolehan Hak atas Tanah dan Bangunan, Raja Grafindo Persada, Jakarta, in 2003

[5] Suryani Hartono, Beberapa Pemikiran Kearah Pembaharuan Hukum Tanah, Bandung, Alumni, 1978

[6] Muhsin, Hukum Agraria Indonesia dalam Perspektif Sejarah, Bandung, Refika Aditama 2007

[7] R. Subekti and R.Tjitrosudibio, Kitab Undang-Undang HUKUM PERDATA, Jakarta, Pradnya Paramita 2008

[8] Soerjono Soekanto and Sri Mamudji, Penelitian Hukum Normatif, Purpose Short, King Garindo Persada, Jakarta, in 2001

[9] Sjaifurahman and Habi Adjie, aspek Pertanggungjawaban Notaris dalam Pembuatan Akta, Bandung, 2011

[10] Act of the Republic of Indonesia of 1945

[11] Book Basic Agrarian Law

[12] Regulation village chief Tungu Godong District of Grobogan No. 02 of 2017 on the lease / Cash Land auction Tungu Village Subdistrict Grobogan Godong Year 2017

[13] http://coretan-berkelas.blogspot.com/2013/11/pengertian-hukum-rukun-dansyarat-sewa.html, On October 27, 2019 at 15:30 